\title{
Involvement of $\gamma$-Aminobutyric Acid (GABA) B Receptors in the Hypotensive Effect of Systemically Administered GABA in Spontaneously Hypertensive Rats
}

\author{
Masayuki Kimura*, Kazuhito Hayakawa and Hiroshi Sansawa \\ Yakult Central Institute for Microbiological Research, 1796 Yaho, Kunitachi, Tokyo 186-8650, Japan
}

Received October 15, 2001 Accepted May 30, 2002

\begin{abstract}
We investigated the effects of intraduodenally (i.d.) administered $\gamma$-aminobutyric acid (GABA) on blood pressure (BP) in anesthetized spontaneously hypertensive rats (SHR) and the mechanism underlying this effect, especially the type of GABA receptor involved in the depressive effect of this amino acid. GABA ( 0.3 to $300 \mathrm{mg} / \mathrm{kg}$, i.d.) caused a dose-related decrease in the BP of $9.20 \pm 3.96$ to $35.0 \pm 5.34 \mathrm{mmHg}$ (mean \pm S.E.M.) that lasted for 30 to $50 \mathrm{~min}$. The minimum effective i.d. dose of GABA was 0.3 to $1.0 \mathrm{mg} / \mathrm{kg}$. Results pertaining to the mechanism underlying the GABA-induced effects on BP were as follows: a) GABA did not alter the BP-related effects of exogenous noradrenaline and acetylcholine; b) pretreatment with hexamethonium decreased the GABA-induced fall in BP, and GABA tended to reduce the pressor response associated with injection of dimethyl phenylpiperazinium; and c) pretreatment with 2-hydroxysaclofen markedly reduced the GABA-induced drop in BP, whereas pretreatment with bicuculline did not. In conclusion, in SHR, low-dose $(0.3$ to $1.0 \mathrm{mg} / \mathrm{kg}$, i.d.) GABA had a hypotensive effect, which may result from attenuation of sympathetic transmission through the activation of $\mathrm{GABA}_{\mathrm{B}}$ receptors at presynaptic or ganglionic sites.
\end{abstract}

Keywords: $\gamma$-Aminobutyric acid (GABA), Blood pressure, Spontaneously hypertensive rat, GABA receptor, Sympathetic nerve

It is well known that $\gamma$-aminobutyric acid (GABA) is one of the major inhibitory neurotransmitters in the central nervous system (CNS) (1), and the central administration of GABA or GABA agonist decreases blood pressure (BP) by reducing sympathetic tone $(2-4)$ or by disrupting the angiotensin II $(5,6)$. Thus it has been confirmed that GABA plays an important role in CNS control of BP.

Oral administration of GABA ( $3 \mathrm{~g}$ daily) to hypertensive patients was first reported about four decades ago, and it was found that oral GABA decreased their BPs without affecting their heart rates (7). Considering that a high dose of GABA administered systemically can reach the brain (8), this effect is thought to occur via a central mechanism. However, a controlled trial of oral GABA had not been conducted until recently, because GABA is thought to cross the blood-brain barrier only minimally $(9-11)$. Therefore most efforts have been concentrated on designing highly hydrophobic derivatives of GABA that can easily permeate brain tissue. Recently, several studies in Japan have

*Corresponding author. FAX: +81-42-577-3020

E-mail: masayuki-kimura@yakult.co.jp addressed the hypotensive effects of various GABAcontaining dietary supplements and other products (1214). These efforts showed that the chronic ingestion of a low dose of GABA decreased systolic BP in spontaneously hypertensive rats (SHR). Because low-dose GABA is not thought to cross the blood-brain barrier, the agent's hypotensive effect has been attributed to a peripheral mechanism.

Several mechanisms (including ganglionic blockade, activation of GABAergic receptors, direct action on vasculature, and inhibition of transmitter release from sympathetic nerve terminals) have been postulated to underlie the hypotensive action of GABA in the peripheral vasculature but are not completely understood $(15-18)$. Furthermore, results from in vivo studies apparently contradict those from in vitro work regarding the type of GABA receptor involved. Namely, GABA $\mathrm{A}_{\mathrm{A}}$ receptor antagonists (e.g., picrotoxin, bicuculline) reduced the hypotensive action of intravenous GABA $(16,19-21)$, whereas the $\mathrm{GABA}_{\mathrm{B}}$ antagonist 2-hydroxysaclofen (but not a $\mathrm{GABA}_{\mathrm{A}}$-receptor antagonist) counteracted the vasodilatory action of GABA in experiments using isolated pulmonary (22), renal (23), 
or mesenteric (24) arteries. Therefore, we designed our investigation first to clarify the minimum effective intraduodenal dose of GABA to confirm whether a low dose of oral GABA has real potential to cause a hypotensive effect. Second, we sought to elucidate the type of receptor involved in the peripheral mechanism underlying the hypotensive action of GABA.

\section{MATERIALS AND METHODS}

\section{Animals and measurements}

Male SHR/Izm (280 to $330 \mathrm{~g}$ ) were purchased from Tokyo Experimental Animals (Tokyo), housed 3 per cage in a room maintained at $22 \pm 2{ }^{\circ} \mathrm{C}$ and at a relative humidity of $55 \% \pm 20 \%$, and allowed to acclimate for at least 1 week before entering the study. The rats were anesthetized by intraperitoneal (i.p.) injection of a mixture of urethane (500 mg/kg; Sigma, St. Louis, MO, USA) and $\alpha$-chloralose (50 mg/kg; Sigma).

To measure BP, the left femoral artery was cannulated, and the cannula was connected to a forced pressure transducer (Blood pressure monitoring kit; Nihon Kohden, Tokyo) and amplifier (AP-621G, Nihon Kohden). Heart rate was recorded with a heart rate meter (AT-601G, Nihon Kohden) and amplifier, which were triggered by the systolic blood pressure.

\section{Drugs}

GABA was purchased from Wako Pure Chemicals (Tokyo), dl-noradrenaline (Nad) from Sankyo (Tokyo), acetylcholine (ACh) from Daiichi Pharmaceutical (Tokyo), bicuculline and 2-hydroxysaclofen from Tocris Cookson (Ellisville, MO, USA), and other chemicals from Sigma.

For i.d. administration, GABA was dissolved in distilled water; GABA for i.v. administration and other chemicals were dissolved in saline. The volumes given were 0.05 to $0.1 \mathrm{~mL} / 100 \mathrm{~g}$ body weight for i.v. administration and $0.5 \mathrm{~mL} / 100 \mathrm{~g}$ for i.d. and i.p. administration.

\section{Administration}

The right femoral vein was cannulated for i.v. drug administration. The stomach wall was partly dissected, and the duodenum was cannulated through the stomach for i.d. administration.

When the time interval between injections of GABA was short, the BP depression was attenuated, similar to the response seen during tachyphylaxis. Therefore, for experiments requiring repeated injection of GABA, it was administered every 20 min for i.v. administration and at $>40$-min intervals for i.d. administration.

The data available in the literature are unclear regarding the initiation and duration of the effect of the various GABA-receptor antagonists we studied. Therefore, we per- formed separate time-course experiments and monitored the effects on BP until $45 \mathrm{~min}$ after the administration of the particular antagonist. We then injected challenge doses of GABA during the interval appropriate to the agonist (as defined through the time-course experiment) and compared the magnitude of the BP depression obtained after administration of both antagonist and GABA with that generated by injecting GABA only.

\section{Data reporting and statistical analyses}

The BP before the administration of drugs (baseline BP) was obtained by calculating the average blood pressure $(\mathrm{ABP}): \mathrm{ABP}=[$ systolic $\mathrm{BP}+$ diastolic $\mathrm{BP}] / 2$. After the administration of drugs, BP was reported as the ABP after administration of i.d. GABA, as the systolic BP (SBP) to monitor the maximal pressor response to Nad or dimethyl phenylpiperazinium (DMPP), and as the diastolic BP (DBP) to follow the maximal depressor response to ACh or i.v. GABA. The relative change (\%) was calculated as (absolute change) / baseline BP $\times 100 \%$.

The data were analyzed by using Student's unpaired $t$-test (SAS system ver.6.12; SAS Institute, Inc., Cary, NC, USA), and differences were considered to be significant at $P<0.05$. All values are presented as the mean \pm S.E.M.

\section{RESULTS}

Dose-related hypotension after intraduodenal administration of $G A B A$

The dose-response curve of the depressor effect of i.d. GABA and a representative chart are shown in Figs. 1 and 2 , respectively. The onset times of the depressor effect (4 to $6 \mathrm{~min}$ ) were almost the same among doses from 10 to $300 \mathrm{mg} / \mathrm{kg}$. However, the onset of the depressor effect apparently was delayed (17 to $24 \mathrm{~min}$ ) at doses less than $3 \mathrm{mg} / \mathrm{kg}$. Dose-related decreases in BP occurred between 0.3 and $300 \mathrm{mg} / \mathrm{kg}$; the baseline $\mathrm{BP}$ was $148 \mathrm{mmHg}$, the absolute decrease was 10 to $35 \mathrm{~mm} \mathrm{Hg}$, and the relative fall ranged from $7 \%$ to $25 \%$. In a typical pattern of hypotension in response to i.d. GABA (Fig. 2), the BP gradually decreased over 30 to $40 \mathrm{~min}$, and the heart rate was not affected (data not shown).

In contrast, i.v. injection of GABA immediately reduced the BP, which then recovered gradually (Fig. 3). The maximum depression in BP after i.v. administration was much greater than that after i.d. administration. The duration rather than the magnitude of depression tended to be increased as doses of GABA increased.

Effect of GABA on the pressor response to Nad and the depressor response to $A C h$

We compared the pressor response to $\mathrm{Nad}(5 \mu \mathrm{g} / \mathrm{kg}$, i.v.) and the depressor response to $\mathrm{ACh}(2 \mu \mathrm{g} / \mathrm{kg}$, i.v. $)$ after 


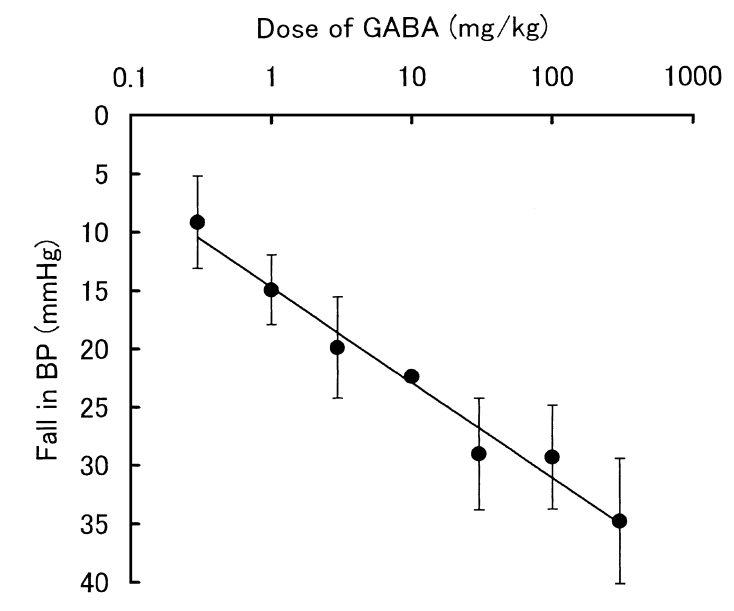

Fig. 1. Dose-response curve of maximum hypotension due to administration of intraduodenal GABA to spontaneously hypertensive rats. The values show the absolute $(\mathrm{mmHg})$ decrease in the average blood pressure. Each point represents the mean \pm S.E.M. of 6 to 13 rats, except for the $10-\mathrm{mg} / \mathrm{kg}$ group $(\mathrm{n}=2)$.

administration of GABA ( 3 or $5 \mathrm{mg} / \mathrm{kg}$, i.v.) with those in the absence of GABA. Administration of GABA had little effect on these responses (Tables 1 and 2). The same result was obtained for i.v. injection of GABA (data not shown).

\section{Effects of ganglionic blocking agents and stimulants}

The depression of the GABA-associated decrease in BP and its duration were attenuated significantly (BP, $P<0.05$; duration, $P<0.01$ ) by treatment with hexamethonium ( $3 \mathrm{mg}$ $/ \mathrm{kg}$, i.v.; Table 3). After we confirmed the pressor response (average, $80 \mathrm{mmHg}$ ) to DMPP (10 to $100 \mu \mathrm{g} / \mathrm{kg}$, i.v.), we
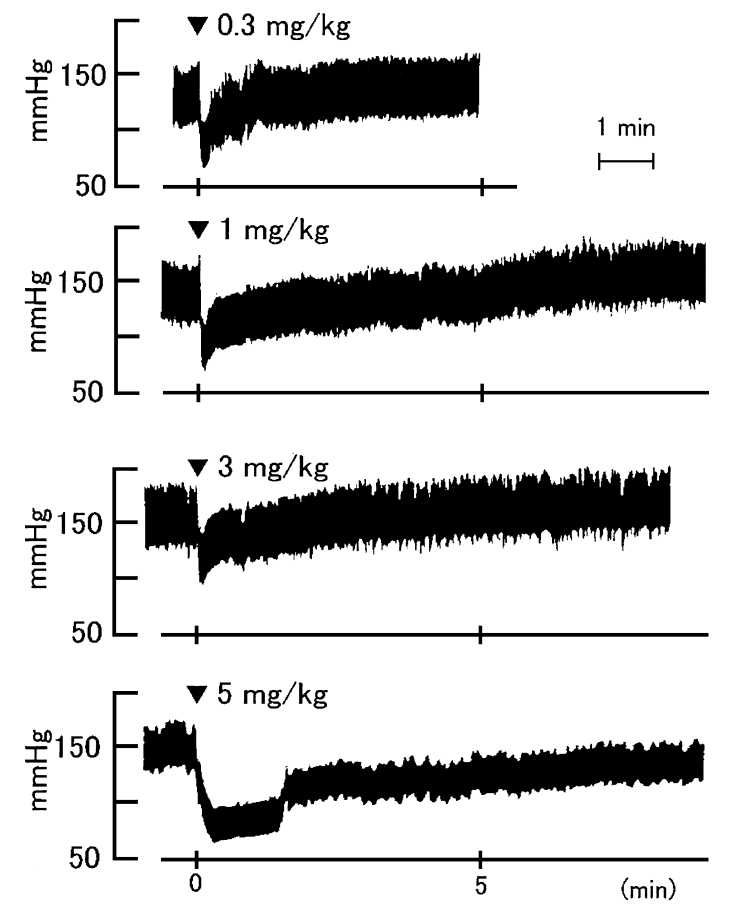

Fig. 3. Pattern of hypotension after intravenous injection of GABA $(0.3,1,3$ or $5 \mathrm{mg} / \mathrm{kg})$ in spontaneously hypertensive rats anesthetized with urethane $(500 \mathrm{mg} / \mathrm{kg})$ and $\alpha$-chloralose $(50 \mathrm{mg} / \mathrm{kg})$. Arrowhead, GABA administration.

then administered GABA (100 or $300 \mathrm{mg} / \mathrm{kg}$, i.d.), followed by DMPP injection. At $300 \mathrm{mg} / \mathrm{kg}$ GABA, the pressor response to DMPP tended to be reduced by an average of $51 \mathrm{mmHg}(40 \% ; \mathrm{n}=6 ; P=0.053)$; however, no change was observed in the relative rise in $\mathrm{BP}$ at $100 \mathrm{mg} / \mathrm{kg}$

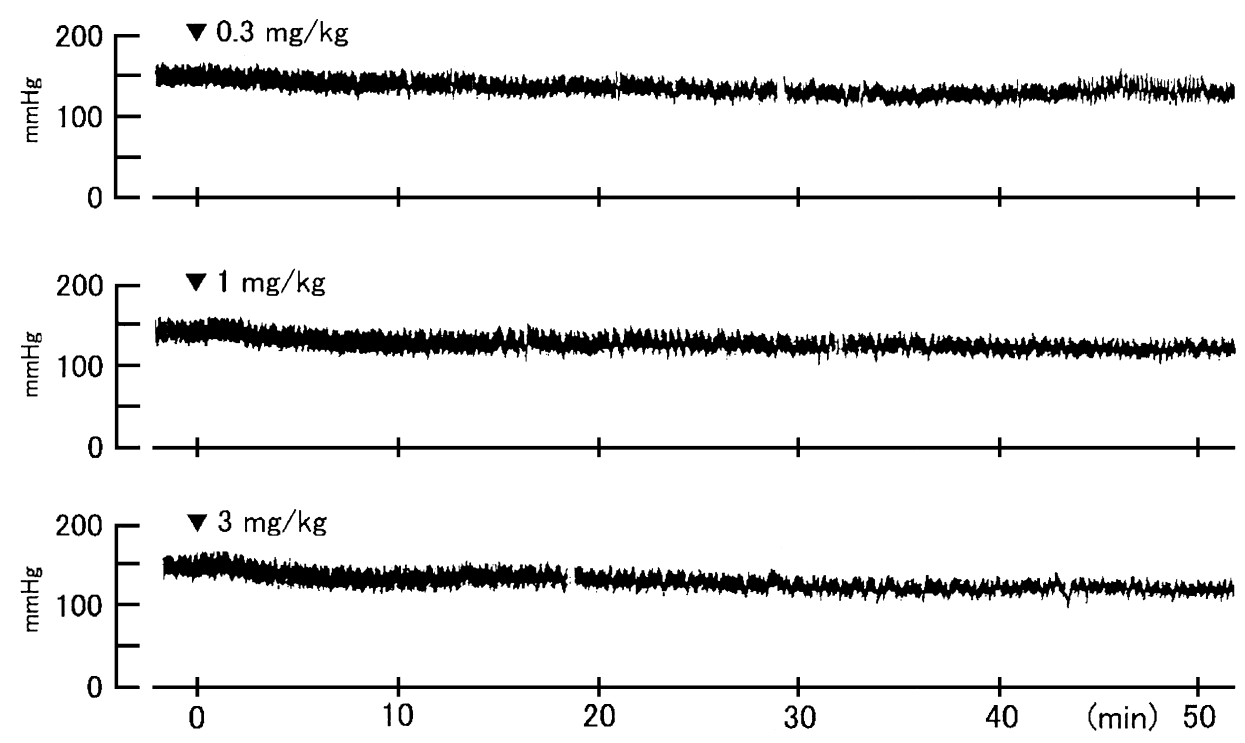

Fig. 2. Pattern of hypotension after intraduodenal administration of GABA $(0.3,1$ or $3 \mathrm{mg} / \mathrm{kg})$ in spontaneously hypertensive rats anesthetized with urethane $(500 \mathrm{mg} / \mathrm{kg})$ and $\alpha$-chloralose $(50 \mathrm{mg} / \mathrm{kg})$. Arrowhead, GABA administration. 
Table 1. Effect of GABA on the noradrenaline (Nad)-induced increase of blood pressure (BP) in spontaneously hypertensive rats

\begin{tabular}{|c|c|c|c|c|c|c|}
\hline \multirow{3}{*}{$\begin{array}{l}\text { Dose of GABA } \\
\quad(\mathrm{mg} / \mathrm{kg})\end{array}$} & \multicolumn{3}{|c|}{ Before GABA } & \multicolumn{3}{|c|}{ After GABA } \\
\hline & \multirow{2}{*}{$\begin{array}{l}\text { Baseline }^{\mathrm{a}} \\
(\mathrm{mmHg})\end{array}$} & \multicolumn{2}{|c|}{$\mathrm{Nad}$} & \multirow{2}{*}{$\begin{array}{l}\text { Baseline }^{\mathrm{a}} \\
(\mathrm{mmHg})\end{array}$} & \multicolumn{2}{|c|}{$\mathrm{Nad}$} \\
\hline & & $\begin{array}{l}\text { Absolute change }{ }^{\mathrm{b}} \\
(\mathrm{mmHg})\end{array}$ & $\begin{array}{c}\text { Relative rise } \mathrm{c}^{\mathrm{c}} \\
(\%)\end{array}$ & & $\begin{array}{l}\text { Absolute change }^{\mathrm{b}} \\
(\mathrm{mmHg})\end{array}$ & $\begin{array}{c}\text { Relative rise } \\
(\%)\end{array}$ \\
\hline 3 & $117 \pm 8.33$ & $87.5 \pm 9.47$ & $77.0 \pm 10.0$ & $118 \pm 19.6$ & $82.5 \pm 11.3$ & $76.1 \pm 19.0$ \\
\hline 5 & $135 \pm 6.30$ & $43.3 \pm 5.47$ & $33.8 \pm 5.53$ & $118 \pm 12.0$ & $61.7 \pm 10.1$ & $52.8 \pm 15.8$ \\
\hline
\end{tabular}

Noradrenaline $(5 \mu \mathrm{g} / \mathrm{kg}$, i.v.) was administered before and after intravenous administration of GABA. Values are the mean \pm S.E.M. of the data from 3 rats. ${ }^{\mathrm{a}}$ (Systolic blood pressure + diastolic blood pressure) $/ 2 .{ }^{\mathrm{b}}$ The difference between the baseline and maximum systolic blood pressures. ${ }^{\mathrm{c}}$ Absolute change / baseline $\mathrm{BP} \times 100 \%$.

Table 2. Effect of GABA on the acetylcholine (ACh)-induced decrease of blood pressure in spontaneously hypertensive rats

\begin{tabular}{|c|c|c|c|c|c|c|}
\hline \multirow{3}{*}{$\begin{array}{l}\text { Dose of GABA } \\
(\mathrm{mg} / \mathrm{kg})\end{array}$} & \multicolumn{3}{|c|}{ Before GABA } & \multicolumn{3}{|c|}{ After GABA } \\
\hline & \multirow{2}{*}{$\begin{array}{l}\text { Baseline }^{\mathrm{a}} \\
(\mathrm{mmHg})\end{array}$} & \multicolumn{2}{|c|}{$\mathrm{ACh}$} & \multirow{2}{*}{$\begin{array}{l}\text { Baseline }^{\mathrm{a}} \\
(\mathrm{mmHg})\end{array}$} & \multicolumn{2}{|c|}{$\mathrm{ACh}$} \\
\hline & & $\begin{array}{c}\text { Absolute change }^{\mathrm{b}} \\
(\mathrm{mmHg})\end{array}$ & $\begin{array}{c}\text { Relative fall }{ }^{\mathrm{c}} \\
(\%)\end{array}$ & & $\begin{array}{l}\text { Absolute change } \\
\quad(\mathrm{mmHg})\end{array}$ & $\begin{array}{c}\text { Relative fall }^{\mathrm{c}} \\
(\%)\end{array}$ \\
\hline 3 & $116 \pm 6.82$ & $-45.8 \pm 8.21$ & $38.5 \pm 4.94$ & $135 \pm 11.5$ & $-53.3 \pm 8.82$ & $39.0 \pm 3.16$ \\
\hline 5 & $145 \pm 7.64$ & $-67.5 \pm 6.29$ & $46.2 \pm 2.25$ & $136 \pm 9.61$ & $-60.0 \pm 10.0$ & $44.8 \pm 1.95$ \\
\hline
\end{tabular}

Acetylcholine $(2 \mu \mathrm{g} / \mathrm{kg}$, i.v. $)$ was administered before and after intravenous administration of GABA. Values are the mean \pm S.E.M. of the data from 3 rats. ${ }^{a}$ (Systolic blood pressure + diastolic blood pressure) / 2. ${ }^{b}$ The difference between the baseline and minimum diastolic blood pressures. ${ }^{\mathrm{c}}$ Absolute change / baseline $\times 100 \%$.

Table 3. Effect of hexamethonium (Hex) on the GABA-induced decrease of blood pressure in spontaneously hypertensive rats

\begin{tabular}{|c|c|c|c|c|c|c|c|c|}
\hline \multirow{3}{*}{$\begin{array}{l}\text { Dose of GABA } \\
\quad(\mathrm{mg} / \mathrm{kg})\end{array}$} & \multicolumn{4}{|c|}{ Before Hex } & \multicolumn{4}{|c|}{ After Hex } \\
\hline & \multirow{2}{*}{$\begin{array}{l}\text { Baseline }^{\mathrm{a}} \\
(\mathrm{mmHg})\end{array}$} & \multicolumn{2}{|c|}{ GABA } & \multirow{2}{*}{$\begin{array}{l}\text { Duration of } \\
\text { hypotension } \\
\quad(\min )\end{array}$} & \multirow{2}{*}{$\begin{array}{l}\text { Baseline }^{\mathrm{a}} \\
(\mathrm{mmHg})\end{array}$} & \multicolumn{2}{|c|}{ GABA } & \multirow{2}{*}{$\begin{array}{l}\text { Duration of } \\
\text { hypotension } \\
\text { (min) }\end{array}$} \\
\hline & & $\begin{array}{l}\text { Absolute change } \\
(\mathrm{mmHg})\end{array}$ & $\begin{array}{c}\text { Relative fall }{ }^{\mathrm{c}} \\
(\%)\end{array}$ & & & $\begin{array}{l}\text { Absolute change } \\
(\mathrm{mmHg})\end{array}$ & $\begin{array}{c}\text { Relative fall }{ }^{\mathrm{c}} \\
(\%)\end{array}$ & \\
\hline 3 & $157 \pm 10.9$ & $-68.3 \pm 5.27$ & $45.0 \pm 3.35$ & $8.20 \pm 1.15$ & $98.8 \pm 19.4$ & $-15.0 \pm 5.40^{\mathrm{d}}$ & $15.2 \pm 3.62^{\mathrm{e}}$ & $2.10 \pm 1.96^{\mathrm{f}}$ \\
\hline 5 & $150 \pm 7.64$ & $-61.7 \pm 3.33$ & $40.1 \pm 2.16$ & $12.5 \pm 2.50$ & $103 \pm 28.9$ & $-13.3 \pm 10.9^{f}$ & $9.20 \pm 6.85^{\mathrm{f}}$ & $0.10 \pm 0.05^{\mathrm{f}}$ \\
\hline
\end{tabular}

GABA was administered intravenously before and after administration of hexamethonium $(3 \mathrm{mg} / \mathrm{kg}$, i.v.). Values are the mean \pm S.E.M. of the data from 4 rats. ${ }^{a}$ (Systolic blood pressure + diastolic blood pressure) $/ 2 .{ }^{b}$ The difference between the baseline and minimum diastolic blood pressures. ${ }^{\mathrm{c}}$ Absolute change / baseline $\times 100 \%$. ${ }^{\mathrm{d}} P<0.001$ (Student's unpaired $t$-test) versus before injecting Hex. ${ }^{\mathrm{e}} P<0.01$ (Student's unpaired $t$-test) versus before injecting Hex. ${ }^{\mathrm{f}} P<0.05$ (Student's unpaired $t$-test) versus before injecting Hex.

\section{GABA (Table 4).}

\section{Effect of GABA receptor antagonists}

Table 5 shows the GABA $(0.3 \mathrm{mg} / \mathrm{kg}$, i.v.)-associated BP depression before and after the administration of bicuculline $\left(1 \mathrm{mg} / \mathrm{kg}\right.$, i.v.), a $\mathrm{GABA}_{\mathrm{A}}$-receptor antagonist. The $\mathrm{BP}$ was slightly increased after the administration of bicuculline (data not shown), but the magnitude of the GABAassociated BP depression (27.2 $\mathrm{mmHg}, 22.4 \%$ ) before the administration of the antagonist was equivalent to that induced by GABA at 3 min after injection of bicuculline $(28.8 \mathrm{mmHg}, 22.7 \%)$ and at $25 \mathrm{~min}$ after bicuculline administration $(31.7 \mathrm{mmHg}, 23.9 \%)$. The duration of the response was also unaffected.
The BP depression due to GABA $(0.3 \mathrm{mg} / \mathrm{kg}$, i.v. $)$ before and after the administration of the $\mathrm{GABA}_{\mathrm{B}}$ antagonist 2-hydroxysaclofen $(1 \mathrm{mg} / \mathrm{kg}, \mathrm{i} . \mathrm{v}$.) is shown in Table 6 . After the administration of 2-hydroxysaclofen, the BP was slightly increased, as for bicuculline (data not shown). Both the magnitude and duration of the depressor response to GABA were reduced at 3 and $25 \mathrm{~min}$ after the administration of 2-hydroxysaclofen. At $45 \mathrm{~min}$ after injection of the antagonist, the reduction had dissipated.

\section{DISCUSSION}

Our present study confirms that a low dose of i.d. GABA decreases the BP of SHR. We observed a linear dose- 
Table 4. Effect of GABA on the dimethyl phenylpiperazinium (DMPP)-induced increase in the blood pressure (BP) of spontaneously hypertensive rats

\begin{tabular}{|c|c|c|c|c|c|c|}
\hline \multirow{3}{*}{$\begin{array}{l}\text { Dose of GABA } \\
(\mathrm{mg} / \mathrm{kg})\end{array}$} & \multicolumn{3}{|c|}{ Before GABA } & \multicolumn{3}{|c|}{ After GABA } \\
\hline & \multirow{2}{*}{$\begin{array}{l}\text { Baseline }^{\mathrm{a}} \\
(\mathrm{mmHg})\end{array}$} & \multicolumn{2}{|c|}{ DMPP } & \multirow{2}{*}{$\begin{array}{l}\text { Baseline }^{\mathrm{a}} \\
(\mathrm{mmHg})\end{array}$} & \multicolumn{2}{|c|}{ DMPP } \\
\hline & & $\begin{array}{l}\text { Absolute change }{ }^{\mathrm{b}} \\
(\mathrm{mmHg})\end{array}$ & $\begin{array}{c}\text { Relative rise }{ }^{\mathrm{c}} \\
(\%)\end{array}$ & & $\begin{array}{l}\text { Absolute change }^{\mathrm{b}} \\
(\mathrm{mmHg})\end{array}$ & $\begin{array}{c}\text { Relative rise } \\
(\%)\end{array}$ \\
\hline 100 & $145 \pm 13.2$ & $93.3 \pm 6.67$ & $64.7 \pm 2.03$ & $124 \pm 13.1$ & $75.0 \pm 2.89$ & $61.2 \pm 6.56$ \\
\hline 300 & $129 \pm 5.39$ & $80.0 \pm 11.4$ & $61.9 \pm 10.2$ & $123 \pm 5.58$ & $50.8 \pm 6.88$ & $39.8 \pm 5.74$ \\
\hline
\end{tabular}

DMPP (10 to $100 \mu \mathrm{g} / \mathrm{kg}$, i.v.) was administered before and after intraduodenal administration of GABA. Values are the mean \pm S.E.M. of the data from 3 to 6 rats. ${ }^{a}$ (Systolic blood pressure + diastolic blood pressure $) / 2 .{ }^{b}$ The difference between the baseline and maximum systolic blood pressures. ${ }^{\mathrm{c}}$ Absolute change / baseline $\times 100 \%$.

Table 5. Effect of bicuculline (Bic) on the GABA-induced decrease in the average blood pressure ${ }^{\mathrm{a}}$ of spontaneously hypertensive rats

\begin{tabular}{lccc}
\hline & Before Bic & \multicolumn{2}{c}{ Min after Bic administration } \\
\cline { 3 - 4 } & & 3 & 25 \\
\hline Baseline (mmHg) & $121 \pm 4.00$ & $126 \pm 5.07$ & $131 \pm 5.43$ \\
GABA & & & \\
Absolute change (mmHg) & & $28.8 \pm 1.83$ & $31.7 \pm 3.58$ \\
Relative fall (\%) & $27.2 \pm 0.88$ & $22.7 \pm 0.86$ & $23.9 \pm 2.10$ \\
Duration (min) & $22.4 \pm 0.39$ & $5.50 \pm 0.64$ & $6.00 \pm 1.34$ \\
\hline
\end{tabular}

GABA $(0.3 \mathrm{mg} / \mathrm{kg}$, i.v. $)$ was administered before and at various points after administration of Bic $(1 \mathrm{mg} / \mathrm{kg}$, i.v.). Values are the mean \pm S.E.M. of the data from 5 to 9 rats. ${ }^{a}$ (systolic blood pressure + diastolic blood pressure) $/ 2$. ${ }^{\mathrm{b}}$ The difference between the baseline and minimum diastolic blood pressures. ${ }^{\mathrm{c}}$ Absolute change $/$ baseline $\times 100 \%$.

Table 6. Effect of the receptor 2-hydroxysaclofen (2-Hy) on the GABA-induced decrease in the average blood pressure $^{\mathrm{a}}$ of spontaneously hypertensive rats

\begin{tabular}{lcccc}
\hline & Before 2-Hy & \multicolumn{3}{c}{ Min after 2-Hy administration } \\
\cline { 3 - 5 } & & 3 & 25 & 45 \\
\hline Baseline (mmHg) & $127 \pm 4.22$ & $128 \pm 4.53$ & $129 \pm 3.98$ & $127 \pm 3.74$ \\
GABA & & & & \\
Absolute change (mmHg) & & & \\
Relative fall (\%) & $27.5 \pm 2.14$ & $20.6 \pm 2.58$ & $20.6 \pm 1.48^{\mathrm{d}}$ & $25.0 \pm 2.24$ \\
Duration (min) & $21.7 \pm 1.41$ & $16.1 \pm 1.94$ & $16.1 \pm 1.25^{\mathrm{d}}$ & $19.7 \pm 1.84$ \\
\hline
\end{tabular}

GABA $(0.3 \mathrm{mg} / \mathrm{kg}$, i.v. $)$ was administered before and at various points after the administration of $2-\mathrm{Hy}(1 \mathrm{mg} / \mathrm{kg}$, i.v.). Values are the mean \pm S.E.M. of the data from 5 to 9 rats. ${ }^{a}$ (systolic blood pressure + diastolic blood pressure) $/ 2$. ${ }^{\mathrm{b}}$ The difference between the baseline and minimum diastolic blood pressures. ${ }^{\mathrm{C}}$ Absolute change $/$ baseline $\times 100 \%$. ${ }^{\mathrm{d}} P<0.05$ (Student's unpaired $t$-test) versus before 2-Hy administration.

related response for i.d. GABA doses of 0.3 to $300 \mathrm{mg} / \mathrm{kg}$ body weight. Although the BP depression for the group receiving $0.3 \mathrm{mg} / \mathrm{kg}$, i.d. was $9.2 \pm 4.0 \mathrm{mmHg}, 2$ of the 6 rats in that group showed no decrease. This result suggests that the minimum effective i.d. GABA dose is actually 0.3 to $1.0 \mathrm{mg} / \mathrm{kg}$. In recent studies of various GABA-containing dietary supplements and other products, regular ingestion of GABA at approximately $1 \mathrm{mg} / \mathrm{kg}$ daily for a several weeks yielded a hypotensive effect in $\operatorname{SHR}(12,14)$. The effective dose of GABA we calculated is similar to that in these studies. Therefore, we have confirmed that lowdose oral GABA decreases the BP of hypertensive rats. Furthermore, we found that mildly hypertensive human patients who daily consumed a fermented milk product containing $10 \mathrm{mg}$ GABA reduced their BPs after 4 weeks without affecting their heart rates (25).

Low-dose GABA is not thought to cross the blood-brain barrier $(9-11)$; therefore, the result mentioned previously 
can be attributed to a peripheral mechanism. Several groups have studied the effect of systemically administered GABA on the cardiovascular system of anesthetized normotensive animals. The results of these studies suggest that dose-related hypotensive effects occurred at doses of 1 to $1000 \mu \mathrm{g}$ $/ \mathrm{kg}(15-17,19)$. Several mechanisms underlying the hypotensive action of GABA in the peripheral vasculature have been postulated, including ganglionic blockade (16), activation of GABAergic receptors $(16,17)$, direct action on vasculature $(15,19)$, and inhibition of transmitter release from sympathetic nerve terminals $(26,27)$.

Administration of GABA to SHR affected neither the pressor response to Nad nor the depressor response to ACh. These findings suggest that GABA lacked a direct effect on Nad and ACh receptors, which occur on the smooth-muscle and endothelial cells of peripheral blood vessels, respectively.

We then evaluated the effect of the ganglionic stimulant DMPP and the ganglionic blocker hexamethonium on the GABA-induced hypotension of SHR. Because DMPP injection after i.v. administration of GABA failed to give a consistent response, we administered GABA intraduodenally, which caused a BP decrease of moderate magnitude and duration. In many animals, administration of GABA tended to reduce the transient pressor response to DMPP $(P=0.053)$. In addition, injection of DMPP prior to administration of GABA often inhibited the GABA-associated depression of the BP (data not shown). Blocking the ganglion by pretreatment with hexamethonium reduced the GABA-induced depression. Thus, GABA seems to inhibit sympathetic neurotransmission at sympathetic ganglia. However, the same effect probably would result if GABA inhibited sympathetic neurotransmission at the presynaptic sites of sympathetic nervous terminals. Regardless, GABA seems to have an effect on sympathetic neurons.

We assessed the effects of two types of GABA-receptor antagonists, bicuculline that acts on $\mathrm{GABA}_{\mathrm{A}}$ receptors and 2-hydroxysaclofen that blocks $\mathrm{GABA}_{\mathrm{B}}$ receptors, on the GABA-induced BP depression. Bicuculline did not affect the depression, which was apparently inhibited by 2hydroxysaclofen. The effect of this inhibitory pattern was to shorten the duration of the depression by approximately one half rather than to attenuate the magnitude of the pronounced depression that occurs soon after i.v. administration of GABA.

Regarding the type of GABA receptor involved in this mechanism, in vivo studies have yielded results that are apparently contradictory to those from in vitro experiments. Administration of a $\mathrm{GABA}_{\mathrm{A}}$-receptor antagonist (picrotoxin, bicuculline) followed by administration of intravenous GABA in experimental animals reduced the hypotensive action of GABA $(16,19-21)$. In contrast, the $\mathrm{GABA}_{\mathrm{B}}$ antagonist 2-hydroxysaclofen (but not $\mathrm{GABA}_{\mathrm{A}}$ antagonists) reduced the GABA-induced vasodilation in various excised peripheral artery models $(22-24)$, and our findings agree with these in vitro results. Thus, primarily $\mathrm{GABA}_{B}$ receptors seem to be involved in the hypotensive effects due to low-dose GABA in SHR.

The reasons why $\mathrm{GABA}_{\mathrm{A}}$ antagonist had no effect on the hypotensive action of GABA in our experiments may be explained as follows. In light of results from various in vitro studies, sympathetic nerve endings probably lack $\mathrm{GABA}_{\mathrm{A}}$ receptors because $\mathrm{GABA}_{\mathrm{A}}$ antagonists have no effect on this region $(22-24)$. In contrast, ganglionic sites may contain only $\mathrm{GABA}_{\mathrm{A}}$ receptors or both $\mathrm{GABA}_{\mathrm{A}}$ and $\mathrm{GABA}_{\mathrm{B}}$ receptors. Regardless of which scenario is correct, it must be accepted that $\mathrm{GABA}_{\mathrm{A}}$ receptors occur at ganglionic sites but not sympathetic nerve endings. Considering the fact that the density of sympathetic innervation is greater in SHR than in normotensive age-matched Wistar Kyoto rats $(28,29)$, the hypotensive effect of systemically administered GABA is effectively concentrated at these nerve ending sites rather than at ganglionic sites in SHR. Therefore, the magnitude of the effect of blocking the $\mathrm{GABA}_{\mathrm{A}}$ receptors at a ganglion will be less apparent in SHR than in normotensive animals. Conversely, in a hypertensive situation, GABA exerts a prominent effect in SHR because of the activation of the $\mathrm{GABA}_{\mathrm{B}}$ receptors at sympathetic nerve endings.

GABA receptors are widespread throughout the peripheral, including in cells of the autonomic nervous system, endocrine cells, exocrine cells, and smooth muscle cells (30). Although there have been no definitive reports to date on the presence of GABA receptors in the peripheral blood vessels themselves, the catabolic enzyme of GABA, glutamate decarboxylase (31), and the metabolic enzyme GABA transaminase (32) occur in various peripheral vessels. More recently, Castelli et al. (33) found that the mRNAs of 2 isoforms of the $\mathrm{GABA}_{\mathrm{B}}$ receptor occurred in all 12 organs examined, including the heart, lung, liver, and small and large intestines. In light of this result, it is reasonable to think that GABA receptors exist in the peripheral vessels of organs that play an important role in defining the systemic blood pressure. However, it remains necessary to demonstrate directly the presence of GABA receptors in these blood vessels.

In conclusion, a low dose of i.d. GABA decreases the BP of SHR; the minimum effective i.d. dose is 0.3 to $1.0 \mathrm{mg}$ $/ \mathrm{kg}$. The mechanism underlying the GABA-associated depression of BP is not related to a direct effect of the drug on the blood vessels. Instead, this effect may be at least partly caused by attenuation of sympathetic neurotransmission following activation of $\mathrm{GABA}_{\mathrm{B}}$ receptors at nerve ending presynaptic or ganglionic sites. 


\section{REFERENCES}

1 Chalmers J: Volhard Lecture: Brain, blood pressure, and stroke. J Hypertens 16, 1849 - 1858 (1998)

2 Person B and Henning M: Effect of GABA analogues on blood pressure and central GABA metabolism in the rat. Acta Pharmacol Toxicol 47, 135 - 143 (1980)

3 Unger Th, Becker H, Retting R and Schwab N: GABAergic stimulation lowers blood pressure in spontaneously hypertensive rats (SHRSP): role of the sympathoadrenal axis. Naunyn Schmiedebergs Arch Pharmacol 322, 171 - 178 (1983)

4 Sasaki S, Lee LC, Nakamura Y, Iyota I, Fukuyama M, Inoue A, Takeda K, Yoshimura M, Nakagawa M and Ijichi H: Hypotension and hypothalamic depression produced by intracerebroventricular injections of GABA in spontaneously hypertensive rats. Jpn Circ J 50, 1140 - 1148 (1986)

5 Brennan $\mathrm{T}$ and Haywood J: GABA inhibition of central angiotensin II and hypertonic CSF pressor responses. Brain Res 267, $261-269$ (1983)

6 Roberts KA, Wright JW and Harding JW: GABA- and bicuculline-induced blood pressure changes in spontaneously hypertensive rats. J Cardiovasc Pharmacol 21, 156 - 162 (1993)

7 Research Group of $\gamma$-Aminobutyric Acid in Tokyo: Clinical aspects on the use of gamma-aminobutyric acid. In Inhibition in the Nervous System and Gamma-Aminobutyric Acid, Edited by Roberts E, Baxter CF, Harreveld AV, Wiersma CAG, Adey WR and Killam KF, pp 579-581, Pergamon Press, Oxford (1960)

8 Biswas B and Carlsson A: Effect of intraperitoneally administered GABA on the locomotor activity of mice. Psychopharmacology (Berl) 59, 91 - 94 (1978)

9 Kuriyama K and Sze PY: Blood-brain barrier to H3- $\gamma$-aminobutyric acid in normal and amino oxyacetic acid-treated animals. Neuropharmacology 10, 103 - 108 (1971)

10 Gelder NM and Elliott KAC: Disposition of $\gamma$-aminobutyric acid administered to mammals. J Neurochem 3, 139 - 143 (1958)

11 Frey HH and Loscher W: Cetyl GABA: effect on convulsant thresholds in mice and acute toxicity. Neuropharmacology 19, $217-220$ (1980)

12 Tsuji K, Ichikawa T, Tanabe N, Abe S, Tarui S and Nakagawa Y: Antihypertensive activities of Beni-Koji extracts and $\gamma$ aminobutyric acid in spontaneously hypertensive rats. Jpn J Nutr 50, 285 - 291 (1992) (text in Japanese with English abstract)

13 Omori M, Yano T, Okamoto J, Tsushida T, Murai T and Higuchi M: Effect of anaerobically treated tea (Gabaron Tea) on blood pressure of spontaneously hypertensive rats. Nippon Nogeikagaku Kaishi 61, 1449-1451 (1987) (text in Japanese with English abstract)

14 Yoshizawa M, Inoue M, Okuda T and Nakamura H: Antihypertensive activities of 2 kinds of rice bran in spontaneous hypertensive rats. Memoirs Osaka Kyoiku Univ 48, 123 - 130 (2000) (text in Japanese with English abstract)

15 Billingsley $\mathrm{M}$ and Suria A: Effects of peripherally administered GABA and other amino acids on cardiopulmonary responses in anesthetized rats and dogs. Arch Int Pharmacodyn 255, $131-140$ (1982)

16 Vemulapalli S and Barletta M: The role of the sympathetic nervous system in the cardiovascular effects of systemically administered gamma-aminobutyric acid. Arch Int Pharmacodyn 267, 46 - 58 (1984)

17 Lim DY, Suh J, Yoo HJ, Kim WS, Kim SB and Lee SK:
Influence of gamma-aminobutyric acid on the changes of blood pressure in rats. Korean J Int Med 5, 23 - 33 (1990)

18 Manzini S, Maggi CA and Meli A: Inhibitory effect of GABA on sympathetic neurotransmission in rabbit ear artery. Arch Int Pharmacodyn 273, 100 - 109 (1985)

19 Billingsley M, Surias A and Gilman R: Evidence for GABA involvement in the peripheral control of blood pressure and vascular resistance. Brain Res Bull 5, Suppl 2, 329 - 333 (1980)

20 Furukawa $\mathrm{T}$ and Kushiku K: Antagonism by gamma-aminobutyric acid of the stimulant effect of angiotensin II on cardiac sympathetic ganglia in spinal dogs. Naunyn Schmiedebergs Arch Pharmacol 317, 149-153 (1981)

21 Löscher W: Cardiovascular effects of GABA, GABA-aminotransferase inhibitors and valproic acid following systemic administration in rats, cats and dogs: pharmacological approach to localize the site of action. Arch Int Pharmacodyn 257, $32-58$ (1982)

22 Starke K and Weitzell R: $\gamma$-Aminobutyric acid and postganglionic sympathetic transmission in the pulmonary artery of the rabbit. J Auton Pharmacol 1, 45 - 51 (1980)

23 Fujimura S, Shimakawa H, Tanioka H, Yoshida M, Suzuki KM, Hisa $\mathrm{H}$ and Satoh S: Effect of GABA on noradrenaline release and vasoconstriction induced by renal nerve stimulation in isolated perfused rat kidney. Br J Pharmacol 127, 109-114 (1999)

24 Hayakawa K, Kimura M and Kamata K: Mechanism underlying $\gamma$-aminobutyric acid-induced antihypertensive effect in spontaneously hypertensive rats. Eur J Pharmacol 438, 107-113 (2002)

25 Inoue K, Shirai T, Ochiai H, Kasao M, Hayakawa K, Kimura M and Sansawa H: Blood-pressure-lowering effect of a novel fermented milk containing $\gamma$-aminobutyric acid (GABA) in mild hypertensives. Eur J Clin Nut (in press)

26 Bowery NG, Doble A, Hill DR, Hudson AL, Shaw JS, Turnbull MJ and Warrington R: Bicuculline-insensitive GABA receptors on peripheral autonomic nerve terminals. Eur J Pharmacol 71, $53-70(1981)$

27 Manzini S, Maggi CA and Meli A: Inhibitory effect of GABA on sympathetic neurotransmission in rabbit ear artery. Arch Int Pharmacodyn Ther 273, 100 - 109 (1985)

28 Lee RM: Vascular changes at the prehypertensive phase in the mesenteric arteries from spontaneously hypertensive rats. Blood Vessels 22, 105 - 126 (1985)

29 Albert V and Campbell GR: Relationship between the sympathetic nervous system and vascular smooth muscle: a morphometric study of adult and juvenile spontaneously hypertensive rat/Wistar-Kyoto rat caudal artery. Heart Vessels 5, 129-139 (1990)

30 Erdö SL and Wolff JR: Short review: $\gamma$-Aminobutyric acid outside the mammalian brain. J Neurochem 54, 363 - 372 (1990)

31 Hamel E, Krause DN and Roberts E: Specific cerebrovascular localization of glutamate decarboxylase activity. Brain Res 223, 199 - 204 (1981)

32 Erdö SL and Bowery NG: Specific, vascular localization of GABA-transaminase in the guinea pig lung. Neurosci Lett $\mathbf{6 8}$, $202-206$ (1986)

33 Castelli MP, Ingianni A, Stefanini E and Gessa GL: Distribution of $\mathrm{GABA}_{\mathrm{B}}$ receptor mRNAs in the rat brain and peripheral organs. Life Sci 64, 1321 - 1328 (1999) 